\title{
Article \\ Cross-Coupling as a Key Step in the Synthesis and Structure Revision of the Natural Products Selagibenzophenones A and B
}

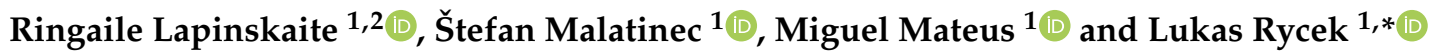 \\ 1 Department of Organic Chemistry, Faculty of Science, Charles University, Albertov 6, \\ 12800 Prague 2, Czech Republic; ringaile.lapinskaite@ftmc.lt (R.L.); stefan.malatinec@natur.cuni.cz (Š.M.); \\ gomesmam@natur.cuni.cz (M.M.) \\ 2 Department of Organic Chemistry, Center for Physical Sciences and Technology (FTMC), Akademijos g. 7, \\ LT-08412 Vilnius, Lithuania \\ * Correspondence: rycekl@natur.cuni.cz; Tel.: +420-22195-1981
}

Citation: Lapinskaite, R.; Malatinec,

Š.; Mateus, M.; Rycek, L. Cross-

Coupling as a Key Step in the

Synthesis and Structure Revision of

the Natural Products

Selagibenzophenones A and B.

Catalysts 2021, 11, 708. https://

doi.org/10.3390/catal11060708

Academic Editors: Kotohiro Nomura,

Takeshi Ohkuma, Alfonso Grassi,

Victorio Cadierno, Carmine Capacchione,

Ken-ichi Fujita, Kei Manabe,

Raffaella Mancuso, Armando Pombeiro,

Fabio Ragaini and Carl Redshaw

Received: 25 May 2021

Accepted: 1 June 2021

Published: 4 June 2021

Publisher's Note: MDPI stays neutral with regard to jurisdictional claims in published maps and institutional affiliations.

Copyright: (c) 2021 by the authors. Licensee MDPI, Basel, Switzerland. This article is an open access article distributed under the terms and conditions of the Creative Commons Attribution (CC BY) license (https:// creativecommons.org/licenses/by/ $4.0 /)$.

\begin{abstract}
Selagibenzophenone A (1) and its isomer selagibenzophenone B (2) were recently described as natural products from Selaginella genus plants with PDE4 inhibitory activity. Herein, we report the first total syntheses of both compounds. By comparing spectroscopic data of the synthetic compounds with reported data for the isolated material, we demonstrate that the structure of one of the two natural products was incorrectly assigned, and that in fact isolated selagibenzophenone A and selagibenzophenone B are identical compounds. The synthetic strategy for both $\mathbf{1}$ and $\mathbf{2}$ is based on a cross-coupling reaction and on the addition of organometallic species to assemble the framework of the molecules. Identifying a suitable starting material with the correct substitution pattern is crucial because its pattern is reflected in that of the targeted compounds. These syntheses are finalized via global deprotection. Protecting the phenols as methoxy groups provides the possibility for partial control over the selectivity in the demethylation thanks to differences in the reactivity of the various methoxy groups. Our findings may help in future syntheses of derivatives of the biologically active natural product and in understanding the structure-activity relationship.
\end{abstract}

Keywords: cross-coupling; natural products; structure revision

\section{Introduction}

Plants from the genus Selaginella (Selaginellaceae) are used in traditional medicine in China, India, and Colombia to treat various ailments such as asthma, dysmenorrhea, or traumatic injuries [1,2]. Species from this genus are sources of structurally diverse natural products, including various bioflavonoids and alkaloids, which can be isolated from different sources as well. Several polyphenolic compounds have been isolated exclusively from species of the Selaginella genus, including selagibenzophenones A (1) [2] and B [3] (2; also referred to as selaphenin A [4] in the literature); selaginpulvilin (3) [5,6], which contains a rather rare bisaryl fluorene motif; and selaginellin (4) [7] (Figure 1). These compounds have shown various biological activities, including antimicrobial [8], cytotoxic [9], antidiabetic [10], anticancer [4], and phosphodiesterase-4 (PDE4) inhibitory properties [2,11].

Several approaches have been developed to synthesize selaginpulvilins, including our formal syntheses of selaginpulvilins C and D [12-17], as well as other unnatural derivatives containing the characteristic diaryl acetylene motif [18]. Syntheses of polyarylated benzophenone containing natural products have not been described yet.

Selagibenzphenone A (1) is a naturally occurring benzophenone derivative, which was recently isolated from Selaginella pulvinata [2]. The determination of the structure revealed that the natural product contains three $4^{\prime}$-hydroxyphenyl rings in positions 2,4 , and 6 of one of the benzophenone rings, the aromatic ring B (Figure 1, 1). The compound has demonstrated inhibitory activity against PDE4, with a promising $\mathrm{EC}_{50}$ value of $1.04 \mu \mathrm{M}$. 
Enzyme PDE4 is involved in the regulation of cyclic adenosine monophosphate (cAMP), and therefore in the modulation of cellular processes [18]. As such, PDE4 is a key target in various indications, including inflammation or memory enhancement (cognitive function stimulation) [19]. Nevertheless, little is known about the other biological properties of selagibenzophenone A (1).

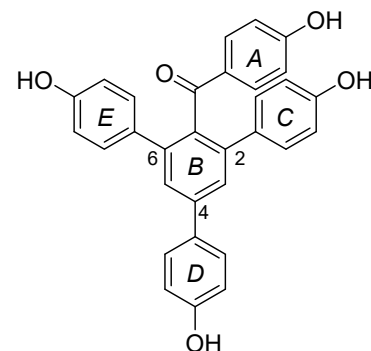

(1)

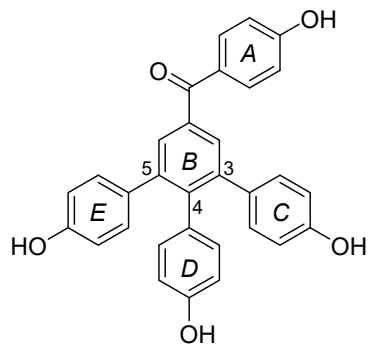

(2)

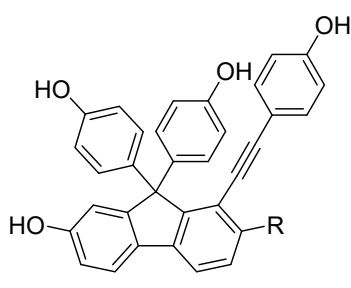

(3)

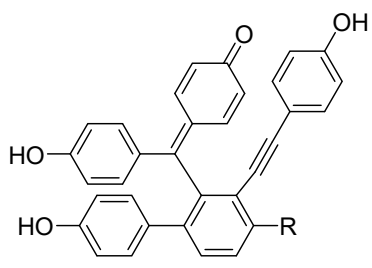

(4)

Figure 1. Examples of natural products isolated from Selaginella plants.

Liang and Wang [4] in 2018, and later Xu and Tan [3] in 2020, reported the isolation of a novel benzophenone analogue, selagibenzophenone B (2) (referred to as selaphenin A by Liang and Wang), with potential anticancer activity. The authors proposed that compound 2 differed from selagibenzophenone A (1) in the position of the substitution of the benzophenone core. Benzophenone 1 contains three 4 '-hydroxyphenyl rings in positions 2, 4 , and 6 of aromatic ring B, whereas selagibenzophenone B (2) has 4'-hydroxyphenyl rings in positions 3, 4, and 5 (Figure 1, 2).

A closer analysis of the reported ${ }^{1} \mathrm{H}$ and ${ }^{13} \mathrm{C}$ NMR spectra of isolated selagibenzophenone A (1) and selagibenzophenone B (2) showed their striking similarity. We put forth two explanations for this similarity: (a) their origin is coincidental, and both compounds actually display similar spectral characteristics; or more likely, (b) only one natural product exists in nature and the structure of the other one was assigned incorrectly. It is not uncommon for the structure of a natural product to be incorrectly solved, as shown by the numerous examples of synthetic work published in the literature that have resulted in subsequent corrections to previously proposed structures of isolated compounds [20,21]. Therefore, we decided to synthesize both molecules. Based on the comparison of spectroscopic data of synthetic and isolated materials, we shed light on this discrepancy in this study. The synthesis and our findings are summarized in the following discussion.

\section{Results and Discussion}

Our synthetic strategy relied on the formation of a benzophenone moiety in both cases via an addition of organometallic species to an aldehyde, followed by re-oxidation to a ketone and a cross-coupling reaction with a suitably substituted starting material. The substitution pattern of the starting aromatic synthon is crucial because it will be reflected in the final substitution pattern of compounds $\mathbf{1}$ and $\mathbf{2}$. We identified commercially available 2,4,6-tribromobenzaldehyde (6) and methyl gallate (8) as suitable starting materials for compounds 1 and $\mathbf{2}$, respectively (Scheme 1 ).
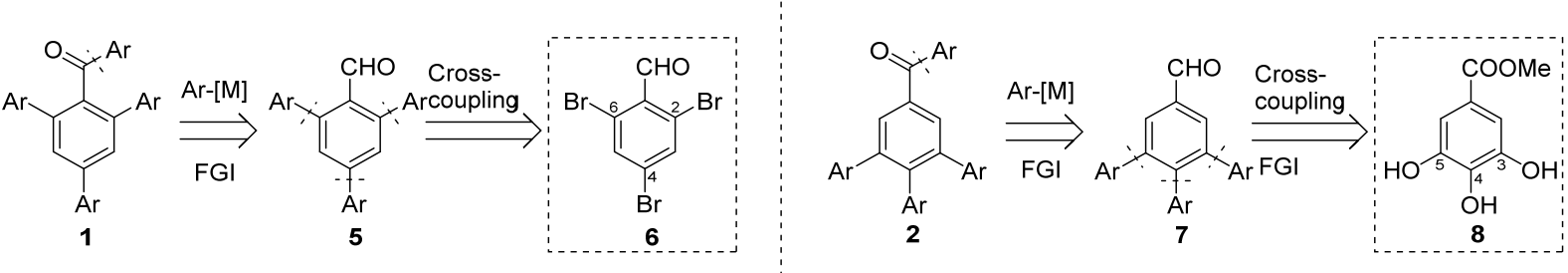<smiles></smiles>

Scheme 1. Retrosynthetic analysis and identification of suitable starting materials (6 and 8). 
The synthesis of selagibenzophenone A (1) commenced with the Suzuki cross-coupling reaction of 2,4,6-tribromobenzaldehyde (6) with a three-fold excess of boronic acid 9 (Scheme 2). In the presence of tetrakis(triphenylphosphine)palladium (0) and potassium carbonate, this reaction provided benzaldehyde 10 in 79\% yield. In the next step, aldehyde 10 was subjected to the Grignard reaction with 4-methoxyphenylmagnesium bromide (11) to furnish secondary alcohol $\mathbf{1 2}$ in $91 \%$ yield. Further oxidation of the alcohol led to the formation of ketone 13 in $74 \%$ yield.

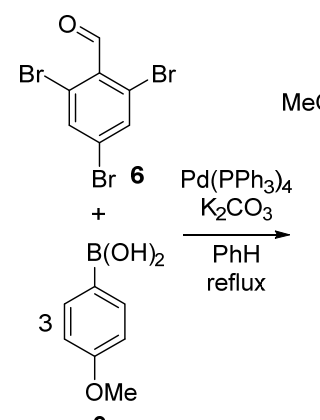

9

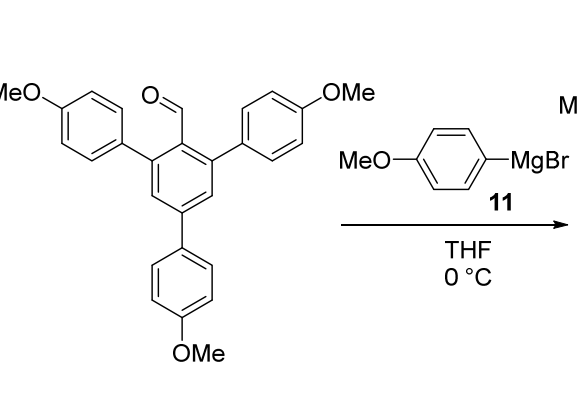

$10,79 \%$

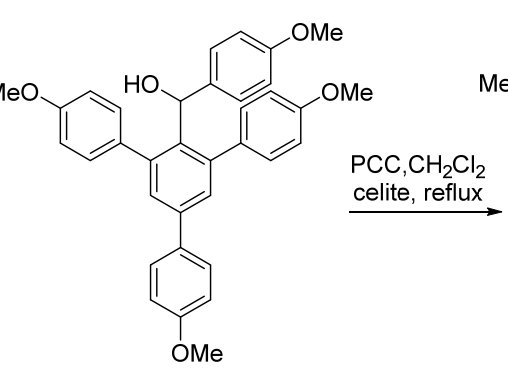

$12,91 \%$

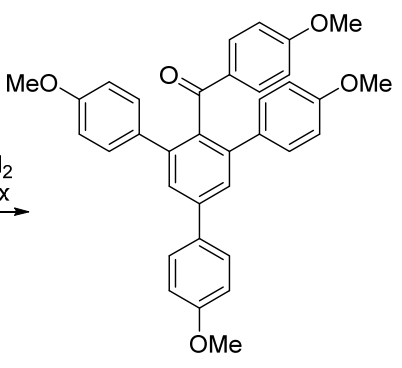

$13,74 \%$

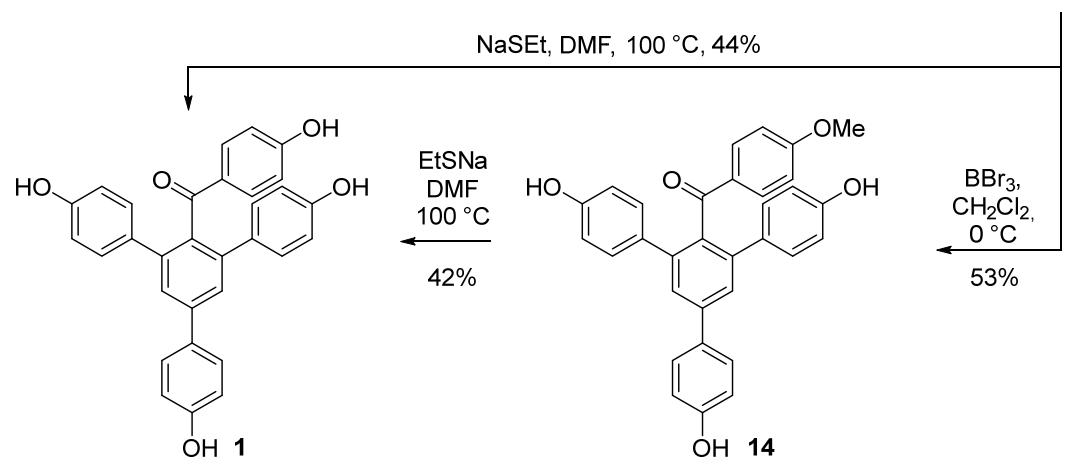

Scheme 2. Synthesis of selagibenzophenone A (1).

Our attempts to demethylate anisole moieties led to an unexpected outcome. Using conditions commonly applied for demethylation of methylphenyl ethers and employing boron tribromide [22,23] in $\mathrm{CH}_{2} \mathrm{Cl}_{2}$ at $0{ }^{\circ} \mathrm{C}$, a new product was formed in $53 \%$ yield and with a significantly higher polarity, indicating the formation of free phenols. However, NMR analysis revealed the presence of one remaining methoxy group at the aromatic ring $\mathrm{A}$, as depicted in the structure of compound $\mathbf{1 4}$ (Scheme 2). The resistance of this methoxy group to demethylation can be explained by the decrease in the Lewis basicity of this particular methoxy group, which was caused by the electron-withdrawing effect of the carbonyl moiety in the para position, thus decreasing the reactivity towards boron tribromide. Such a reactivity has already been described in the literature for similar systems [24]. Despite the fact that such a selectivity in the deprotection step can be beneficial in the synthesis of derivatives of this natural product for medicinal chemistry purposes and for understanding the structure-activity relationship, this approach is not applicable for the synthesis of the natural product. Increasing the reaction temperature to $25^{\circ} \mathrm{C}$ or to a refluxing temperature did not change the outcome of the reaction either. In addition, applying harsh conditions, as described in the synthesis of related selaginpulvilins $C$ and $\mathrm{D}$, namely using neat MeMgI at $160{ }^{\circ} \mathrm{C}[12,15]$, led to the decomposition of the material and to the formation of a complex mixture of products.

Considering the above, we hypothesized that the remaining methoxy group could also be cleaved using nucleophilic instead of electrophilic conditions. Indeed, when applying sodium ethanethiolate in DMF at $100^{\circ} \mathrm{C}$ [24], the remaining methoxy group was cleaved and tetraphenol 1 was formed in $42 \%$ yield. Moreover, subjecting the fully protected compound $\mathbf{1 3}$ to the same reaction conditions resulted in the cleavage of all methoxy 
groups and in the formation of the desired product 1 in $44 \%$ yield (Scheme 2). However, we found that this demethylation was not reproducible despite extensive research. The reasons for the lack of reproducibility of this protocol remain elusive.

These unsatisfactory results, combined with the unpractical use of a large excess of sodium ethylthiolate, which has an unpleasant odor, prompted us to develop a more reliable route to compound $\mathbf{1}$, employing an alternative and easily removable tert-butyldimethyl silyl (TBS) protective group. Therefore, the second-generation synthesis began with the synthesis of boronic acid $\mathbf{1 7}$ from 4-bromophenol (15), which was achieved in two steps, namely protection of the phenol moiety, yielding $91 \%$ of bromide 16; and introduction of boronic acid via lithium-halogen exchange, reaction with isopropyl borate, and in situ hydrolysis. Suzuki coupling of aldehyde $\mathbf{6}$ and boronic acid $\mathbf{1 7}$ under similar conditions to those applied in the previous synthesis provided aldehyde 18 in 79\% yield. In the next step, aryl bromide $\mathbf{1 6}$ was treated with $t$-butyl lithium and the resulting organolithium species reacted with aldehyde $\mathbf{1 8}$. The immediate oxidation of the crude reaction mixture provided ketone 19 in 57\% yield over two steps. Global deprotection of TBS groups employing HF-pyridine resulted in the formation of the natural product (1) in $82 \%$ yield (Scheme 3).
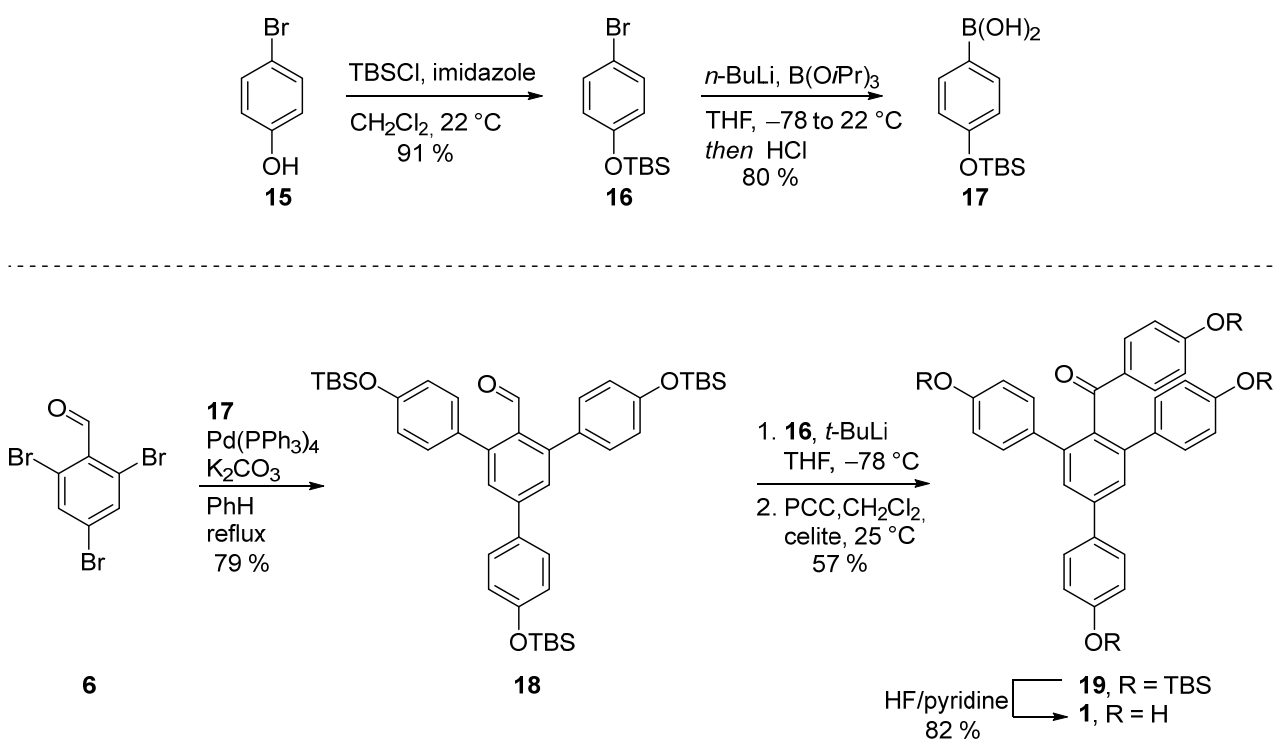

Scheme 3. Improved synthesis of selagibenzophenone A (1).

In the synthesis of selagibenzophenone B (2), the hydroxy groups of gallate 8 were converted into triflates in a reaction with triflic anhydride in the presence of triethylamine (Scheme 4). This reaction provided the desired triflate 20 in 96\% yield. Suzuki crosscoupling of compound 20 and 3.15 equivalents of 4-methoxyphenyl boronic acid (9) proceeded smoothly and furnished the trisarylated aromatic ester 21 in $71 \%$ yield. Reduction of the ester moiety in compound 21 was pursued next. When using DIBAL-H at $-78^{\circ} \mathrm{C}$, this reaction resulted in the formation of the desired aldehyde, albeit with partial overreduction to alcohol. Therefore, the crude reaction mixture was subjected to re-oxidation with pyridinium chlorochromate (PCC) to provide aldehyde 22 in $83 \%$ yield. Alternatively, $\mathrm{LiAlH}_{4}$ can be used for a complete reduction of the ester to primary alcohol, and after re-oxidation with PCC, aldehyde 22 was obtained in $72 \%$ overall yield. The aromatic ring D was introduced into the structure via Grignard reaction with 4-methoxyphenylmagnesium bromide. The resulting alcohol was subjected to the PCC-mediated oxidation without further purification and yielded the desired ketone $\mathbf{2 3}$ in $61 \%$ yield (over two steps). To our delight, subjecting compound 23 to $\mathrm{BBr}_{3}$ in $\mathrm{CH}_{2} \mathrm{Cl}_{2}$ at room temperature resulted in the formation of the desired polyphenol $\mathbf{2}$ in $36 \%$ yield along with monomethoxy derivative 24 in $48 \%$ yield (Scheme 4 ). 

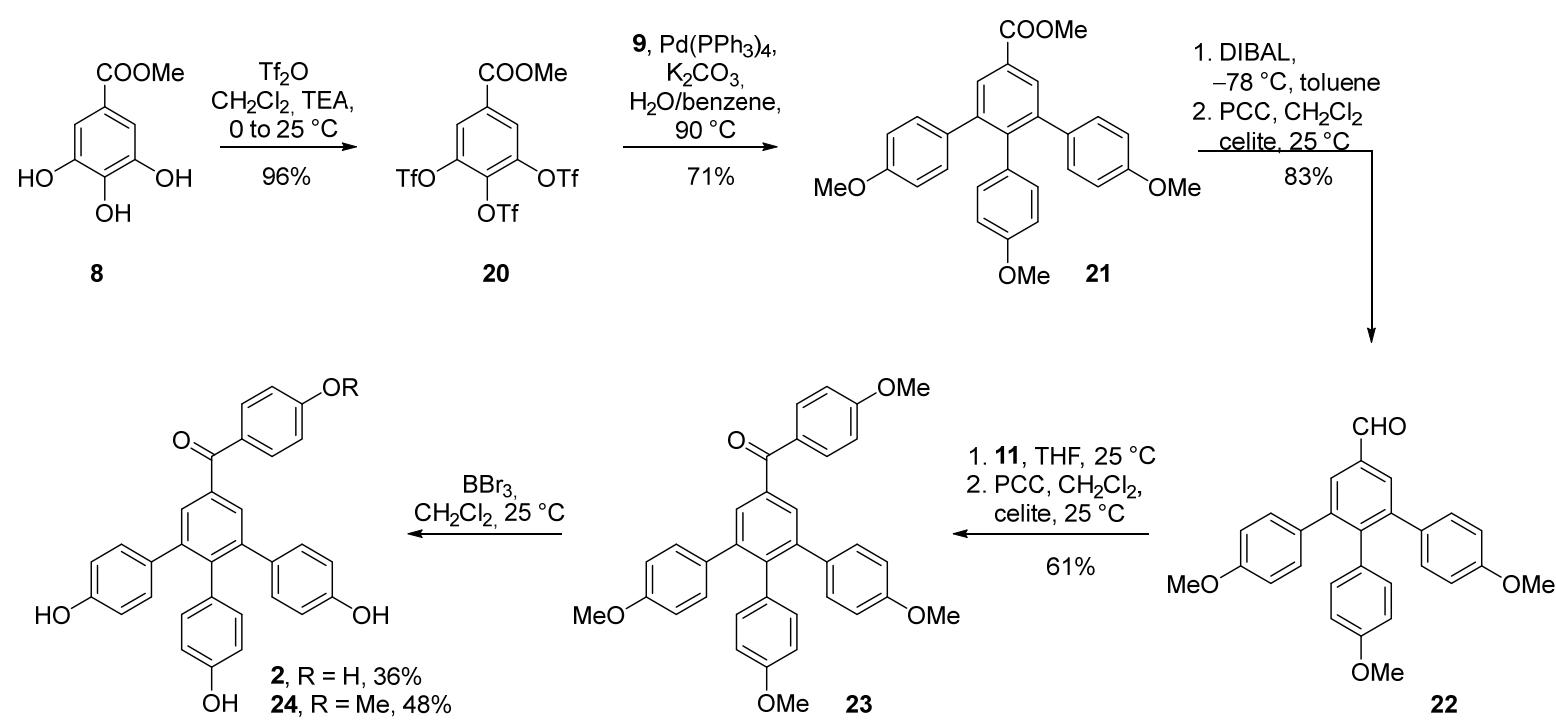

Scheme 4. Synthesis of selagibenzophenone B (2).

Having both desired compounds $\mathbf{1}$ and $\mathbf{2}$ in hand, we compared their analytical data. The spectra of the synthetic compounds $\mathbf{1}$ and $\mathbf{2}$ are clearly different (Figure 2). In fact, the change in the chemical shifts of corresponding protons of these molecules in the ${ }^{1} \mathrm{H} \mathrm{NMR}$ spectra are more significant than it appears at first glance. The chemical shift in the signals of aromatic rings $\mathrm{A}$ and $\mathrm{D}$ in both compounds are strongly influenced by the anisotropic effect of aromatic rings $\mathrm{C}$ and $\mathrm{E}$. In compound 1 , protons $\mathrm{H}^{\mathrm{A}}$ and $\mathrm{H}^{\mathrm{B}}$ (ring $\mathrm{A}$ ) are shielded by aromatic rings $\mathrm{C}$ and $\mathrm{E}$ and shifted upfield relative to protons $\mathrm{H}^{\mathrm{A}}$ and $\mathrm{H}^{\mathrm{B}}$ in compound $2\left(1: \mathrm{H}^{\mathrm{A}}=7.42 \mathrm{ppm}\right.$ and $\mathrm{H}^{\mathrm{B}}=6.60 \mathrm{ppm} ; 2 \mathrm{H}^{\mathrm{A}}=7.78 \mathrm{ppm}$ and $\left.\mathrm{H}^{\mathrm{B}}=6.76 \mathrm{ppm}\right)$. Conversely, in compound 2, the shielding zone of rings $C$ and $E$ affects the protons of the aromatic ring $\mathrm{D}$, meaning the signals $\mathrm{H}^{\mathrm{C}}$ and $\mathrm{H}^{\mathrm{D}}$ are shifted upfield in compound 2 relative to those in compound $1\left(1: \mathrm{H}^{\mathrm{C}}=7.58 \mathrm{ppm}\right.$ and $\mathrm{H}^{\mathrm{D}}=6.90 \mathrm{ppm} ; 2 \mathrm{H}^{\mathrm{C}}=6.66 \mathrm{ppm}$ and $\mathrm{H}^{\mathrm{D}}=6.48 \mathrm{ppm}$ ). The effect is most significant on proton $\mathrm{H}^{\mathrm{C}}$, for which the difference in chemical shift is nearly one ppm. Similarly, in both compounds, protons $\mathrm{H}^{\mathrm{E}}$ and $\mathrm{H}^{\mathrm{F}}$ from rings $\mathrm{C}$ and $\mathrm{E}$ are affected by the anisotropic shielding of either conjugated system of the carbonyl group together with ring $\mathrm{A}$ in compound $\mathbf{1}$ or by aromatic ring $\mathrm{D}$ in compound 2 . The chemical shifts of protons $\mathrm{H}^{\mathrm{E}}$ (1: $\left.7.11 \mathrm{ppm} ; 26.90 \mathrm{ppm}\right)$ clearly show that the shielding of the aromatic ring $\mathrm{D}$ in $\mathbf{2}$ is stronger than that of the conjugated carbonyl-aromatic ring $\mathrm{A}$ system in $\mathbf{1}$.

Based on the findings described above, the coincidental similarity for the spectra of isolated selagibenzophenones A and B was ruled out. Consequently, the structure of one of the isolated compounds was incorrectly assigned. For this reason, we compared the spectra of both synthetic compounds $\mathbf{1}$ and $\mathbf{2}$ with the spectra of the isolated selagibenzophenones reported in the literature. The chemical shift in the signals observed in ${ }^{1} \mathrm{H}$ and ${ }^{13} \mathrm{C}$ NMR spectra are summarized in Table S1 (see supplementary information). The reported spectra of both isolated compounds correspond to the spectra of synthetic compound 1. As such, the structure of the isolated selagibenzophenone B was assigned incorrectly and the compound previously reported as selagibenzophenone B was in fact selagibenzophenone A. 

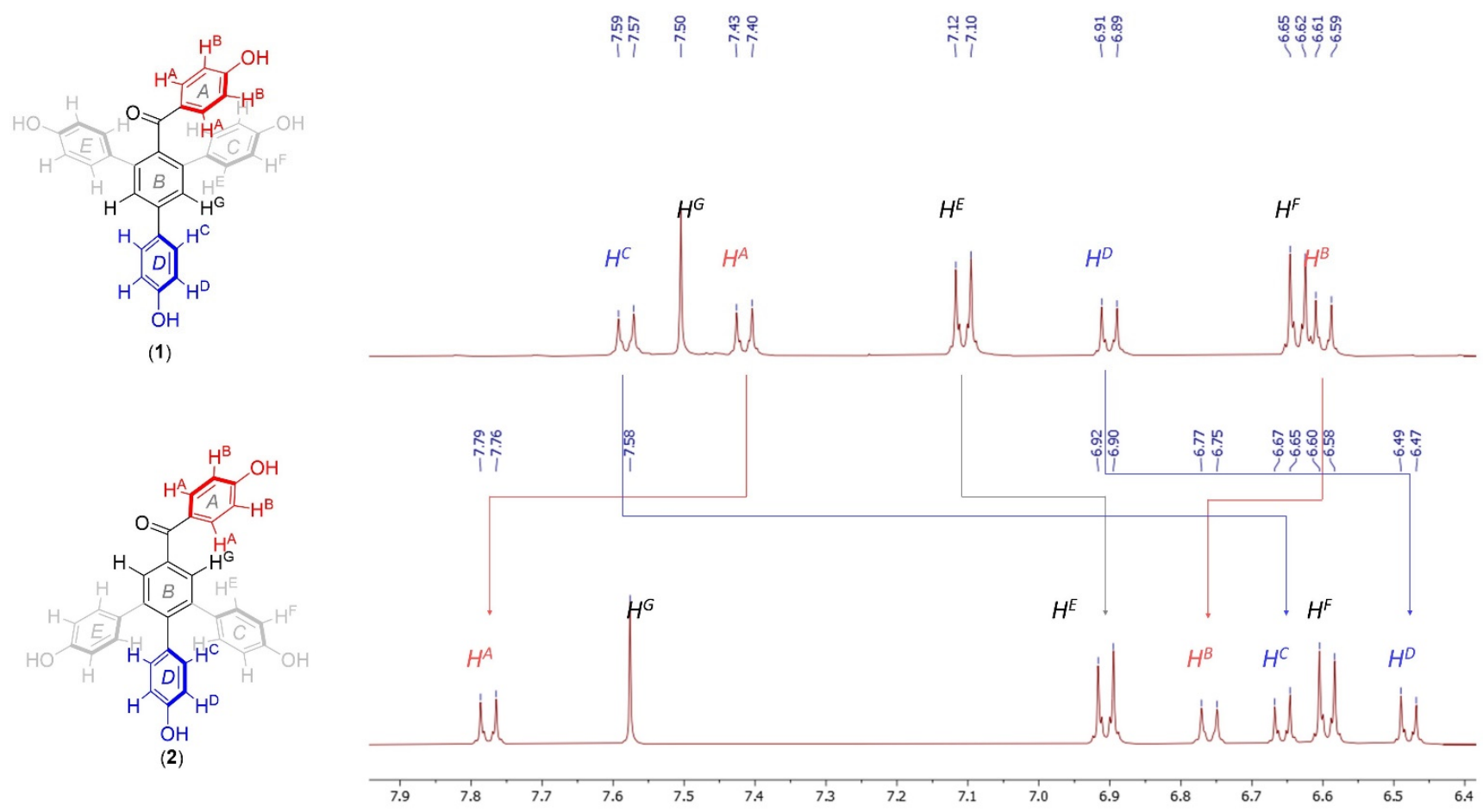

Figure 2. Comparison of the ${ }^{1} \mathrm{H}$ NMR spectra of synthetic compounds $\mathbf{1}$ and $\mathbf{2}$.

\section{Materials and Methods}

\subsection{General}

All of the chemicals were purchased from the common sources, namely Merck KGaA (Darmstadt, Germany), Acros Organics (part of Thermo Fisher, Geel, Belgium), Alfa Aesar (part of Thermo Fisher, Kandel, Germany), Strem Chemicals (Kehl, Germany), PENTA Chemicals (Prague, Czech Republic), Fluorochem (Headfield, UK), and Cambridge Isotope Laboratories (Tewksbury, MA, USA), Inc. All of the reagents were used without further purification unless otherwise noted. Solvents used in the reactions were distilled and dried prior the use. The reactions were monitored by TLC using Merck TLC (Merck KGaA, Darmstadt, Germany) silica gel 60 F254 plates, using UV lamp (254 nm) detection and Hanessian's stain (CAM). NMR spectra were recorded on a Bruker Avance III spectrometer (Bruker, Billerica, MA, United States, $400 \mathrm{MHz}$ and $600 \mathrm{MHz}$ for ${ }^{1} \mathrm{H}$ NMR and $100 \mathrm{MHz}$ and $150 \mathrm{MHz}$ for ${ }^{13} \mathrm{C}$ NMR, respectively) and Varian NMR Solutions 300 (Varian, Inc., Palo Alto, CA, USA, $300 \mathrm{MHz}$ for ${ }^{1} \mathrm{H}$ NMR and $75 \mathrm{MHz}$ for ${ }^{13} \mathrm{C}$ NMR). All chemical shifts $\delta$ are reported in ppm with a reference to a residual solvent. Mass spectrometry was performed on a VG-Analytical ZAB SEQ (VG Analytical, Manchester, UK). Infrared spectrum were measured in KBr with a Thermo Nicolet AVATAR 370 FT-IR spectrometer (Thermo Fisher Scientific Inc., Waltham, MA, USA). Melting points were determined using a MXBAOHENG Melting Point Apparatus with Microscope X-4 (MRC laboratoryinstruments, Harlow, UK). Unless otherwise stated, for reactions that required heating, these were carried out using the oil bath as the heat source. Copies of the NMR spectra are available in supplementary information.

\subsection{Synthesis}

3.2.1. Synthesis of $4,4^{\prime \prime}$-dimethoxy-5'-(4-methoxyphenyl)-[1, $1^{\prime}: 3^{\prime}, 1^{\prime \prime}$-terphenyl]-2'carbaldehyde (10)

2,4,6-Tribromobenzaldehyde 6 (0.73 mmol, $250 \mathrm{mg}), \mathrm{Pd}\left(\mathrm{PPh}_{3}\right)_{4}(0.037 \mathrm{mmol}, 5 \mathrm{~mol} \%$, $42 \mathrm{mg}$ ), $\mathrm{K}_{2} \mathrm{CO}_{3}(2.56 \mathrm{mmol}, 353 \mathrm{mg}$ ), and (4-methoxyphenyl)boronic acid 9 (2.3 mmol, $355 \mathrm{mg}$ ) were dissolved in a degassed mixture of benzene and $\mathrm{H}_{2} \mathrm{O}(5: 1,6 \mathrm{~mL})$. The reaction was heated in a closed vial at $90{ }^{\circ} \mathrm{C}$ for $16 \mathrm{~h}$. Then, the reaction mixture was concentrated 
and the product was purified with column chromatography (EA:Hex 1:6 to 1:4). The reaction yielded $574 \mathrm{mg}(93 \%)$ of product in the form of a yellow glassy oil. $\mathrm{R}_{f}=0.3$ [EA:Hex (1:4)]; IR (KBr) 3033, 2999, 2954, 2933, 2906, 2835, 2754, 1693, $1608 \mathrm{~cm}^{-1}$; ${ }^{1} \mathrm{H}$ NMR $\left(400 \mathrm{MHz}, \mathrm{CDCl}_{3}\right) \delta 9.97(\mathrm{~s}, 1 \mathrm{H}), 7.70-7.59(\mathrm{~m}, 2 \mathrm{H}), 7.54(\mathrm{~s}, 2 \mathrm{H}), 7.41-7.32(\mathrm{~m}, 4 \mathrm{H}), 7.10-6.91$ $(\mathrm{m}, 6 \mathrm{H}), 3.88(\mathrm{~s}, 6 \mathrm{H}), 3.86(\mathrm{~s}, 3 \mathrm{H}) ;{ }^{13} \mathrm{C} \mathrm{NMR}\left(100 \mathrm{MHz}, \mathrm{CDCl}_{3}\right) \delta 193.4,160.2,159.4(2 \mathrm{C})$, 145.1 (2C), 143.9, 132.3 (2C), 132.0, 131.3, 131.0 (4C), 128.6 (2C), $128.4(2 \mathrm{C}), 114.6(2 \mathrm{C}), 113.8$ (4C), 55.5 (3C); HRMS (ESI) calculated for $\mathrm{C}_{28} \mathrm{H}_{25} \mathrm{O}_{4}\left(\mathrm{MS}+\mathrm{H}^{+}\right)$: 425.1747; found 425.1746 .

3.2.2. Synthesis of $\left(4,4^{\prime \prime}\right.$-dimethoxy-5'-(4-methoxyphenyl)-[1, $1^{\prime}: 3^{\prime}, 1^{\prime \prime}$-terphenyl $]-4^{\prime}$-yl)(4methoxyphenyl)methanol (12)

A solution of (4-methoxyphenyl)magnesium bromide 11 (1 M in THF, $0.1 \mathrm{mmol}, 0.1 \mathrm{~mL}$ ) was added in a dropwise manner to a solution of 4, $4^{\prime \prime}$-dimethoxy-5'-(4-methoxyphenyl)$\left[1,1^{\prime}: 3^{\prime}, 1^{\prime \prime}\right.$-terphenyl]-2'-carbaldehyde $10(0.071 \mathrm{mmol}, 34 \mathrm{mg})$ in THF $(1 \mathrm{~mL})$ at $0{ }^{\circ} \mathrm{C}$. After stirring the reaction in the ice bath for $40 \mathrm{~min}$, it was quenched with saturated $\mathrm{NH}_{4} \mathrm{Cl}$ solution $(3 \mathrm{~mL})$. The product was extracted with EA $(3 \times 5 \mathrm{~mL})$. Combined organic phases were dried over $\mathrm{Na}_{2} \mathrm{SO}_{4}$, then filtered and concentrated. The product was purified by column chromatography (gradient eluent EA:Hex 1:6 to 1:4). The reaction yielded $30 \mathrm{mg}$ (79\%) of product in the form of a colorless glassy oil. $\mathrm{R}_{f}=0.2$ [EA:Hex (1:4)]; IR (KBr) 3556, 3033, 2999, 2952, 2933, 2906, 2835, 2044, 1888, 1736, $1608 \mathrm{~cm}^{-1} ;{ }^{1} \mathrm{H}$ NMR $\left(400 \mathrm{MHz}, \mathrm{CDCl}_{3}\right)$

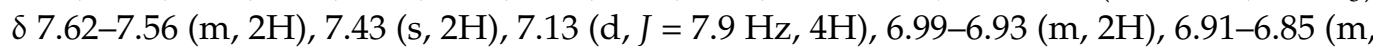
$2 \mathrm{H}), 6.84-6.78(\mathrm{~m}, 4 \mathrm{H}), 6.73-6.67(\mathrm{~m}, 2 \mathrm{H}), 5.95(\mathrm{~d}, J=9.2 \mathrm{~Hz}, 1 \mathrm{H}), 3.84(\mathrm{~s}, 3 \mathrm{H}), 3.81(\mathrm{~s}, 6 \mathrm{H})$, $3.77(\mathrm{~s}, 3 \mathrm{H}), 2.14(\mathrm{~d}, J=10.1 \mathrm{~Hz}, 1 \mathrm{H}) ;{ }^{13} \mathrm{C} \mathrm{NMR}\left(100 \mathrm{MHz}, \mathrm{CDCl}_{3}\right) \delta 159.5,158.9(2 \mathrm{C}), 158.1$, 142.8 (2C), 139.1, 138.0 (2C), 134.0 (2C), 132.7, 130.8 (4C), 128.8 (2C), 128.2 (2C), 126.7 (2C), $114.4(2 \mathrm{C}), 113.5$ (4C), 113.2 (2C), 72.3, 55.5, 55.4 (3C); HRMS (ESI) calculated for $\mathrm{C}_{35} \mathrm{H}_{31} \mathrm{O}_{4}$ : 515.2217; found 515.2219.

3.2.3. Synthesis of $\left(4,4^{\prime \prime}\right.$-dimethoxy-5'-(4-methoxyphenyl)-[1, $1^{\prime}: 3^{\prime}, 1^{\prime \prime}$-terphenyl $]-4^{\prime}$-yl)(4methoxyphenyl)methanone (13)

PCC (0.483 mmol, $104 \mathrm{mg}),\left(4,4^{\prime \prime}\right.$-dimethoxy-5'-(4-methoxyphenyl)-[1, $1^{\prime}: 3^{\prime}, 1^{\prime \prime}$-terphenyl]$4^{\prime}$-yl)(4-methoxyphenyl)methanol $12(0.4 \mathrm{mmol}, 214 \mathrm{mg})$, and Celite ${ }^{\circledR}(214 \mathrm{mg})$ were suspended in DCM (15 mL) and refluxed for 24 hours. Then reaction mixture was filtered through a plug of Celite ${ }^{\circledR}$ and concentrated. On TLC, the conversion was visible only when the plate was stained with Hanessian's stain (CAM). The product was purified by column chromatography (EA:Hex 1:6 to 1:4). Reaction yielded $156 \mathrm{mg}$ (74\%) of product in the form of a colorless glassy oil. $\mathrm{R}_{f}=0.2$ [EA:Hex (1:4)]; $\mathrm{mp}=180-182{ }^{\circ} \mathrm{C}(\mathrm{DCM}: \mathrm{MeOH})$, lit. 173-174 ${ }^{\circ} \mathrm{C}$ [25] (AcOH); IR (KBr) 3033, 3001, 2956, 2933, 2908, 2835, 2048, 1660, 1606, 1597 $\mathrm{cm}^{-1} ;{ }^{1} \mathrm{H}$ NMR $\left(400 \mathrm{MHz}, \mathrm{CDCl}_{3}\right) \delta 7.67-7.61(\mathrm{~m}, 2 \mathrm{H}), 7.58-7.53(\mathrm{~m}, 4 \mathrm{H}), 7.26-7.22(\mathrm{~m}, 4 \mathrm{H})$, 7.03-6.98 (m, 2H), 6.79-6.73 (m, 4H), 6.70-6.64 (m, 2H), $3.87(\mathrm{~s}, 3 \mathrm{H}), 3.76(\mathrm{~s}, 3 \mathrm{H}), 3.74(\mathrm{~s}, 6 \mathrm{H})$; ${ }^{13} \mathrm{C} \mathrm{NMR}\left(100 \mathrm{MHz} \mathrm{CDCl}_{3}\right) \delta 197.9,163.2,159.7,158.9$ (2C), 141.2, 140.9, 136.9 (2C), 133.1 (2C), 132.8, 131.9, 131.7 (2C), $130.4(4 \mathrm{C}), 128.4(2 \mathrm{C}), 127.2(2 \mathrm{C}), 114.5(2 \mathrm{C}), 113.7(4 \mathrm{C}), 113.4$ (2C), 55.5, 55.4, 55.3 (2C); HRMS (ESI) calculated for $\mathrm{C}_{35} \mathrm{H}_{31} \mathrm{O}_{5}(\mathrm{M}+\mathrm{H})$ : 531.2166; found 531.2167 .

3.2.4. Synthesis of $\left(4,4^{\prime \prime}\right.$-dihydroxy-5' -(4-hydroxyphenyl)-[1, $1^{\prime}: 3^{\prime}, 1^{\prime \prime}$-terphenyl]-4' -yl)(4methoxyphenyl)methanone (14)

$\mathrm{BBr}_{3}$ solution ( $1 \mathrm{M}$ in heptane, $\left.0.415 \mathrm{mmol}, 0.415 \mathrm{~mL}\right)$ was added into a solution of $\left(4,4^{\prime \prime}\right.$ dimethoxy-5'-(4-methoxyphenyl)-[1,1':3', $1^{\prime \prime}$-terphenyl]-4'-yl)(4-methoxyphenyl)methanone $(0.094 \mathrm{mmol}, 50 \mathrm{mg})$ in DCM $(2 \mathrm{~mL})$ in a dropwise manner at $0{ }^{\circ} \mathrm{C}$. The reaction was stirred at room temperature for $16 \mathrm{~h}$. The reaction mixture was quenched with a solution of $\mathrm{NaHSO}_{3}(50 \%, 5 \mathrm{~mL})$, then extracted with EA $(3 \times 7 \mathrm{~mL})$. Organic phases were combined, washed with brine $(5 \mathrm{~mL})$, dried over $\mathrm{Na}_{2} \mathrm{SO}_{4}$, filtered, and concentrated under reduced pressure. The product was purified by column chromatography (EA:Hex 1:4 to 1:1). The reaction yielded $24 \mathrm{mg}(53 \%)$ of product in the form of a colorless glassy oil. $\mathrm{R}_{f}=0.2$ [EA:Hex (1:1)]; IR (KBr) 3323, 3070, 3033, 3014, 2964, 2935, 2839, 2044, 1894, 1643, 1610, 
$1591 \mathrm{~cm}^{-1} ;{ }^{1} \mathrm{H}$ NMR $\left(600 \mathrm{MHz}, \mathrm{MeOD}-d_{4}\right) \delta$ 7.59-7.56 (m, 2H), 7.51-7.48 (m, 4H), 7.12-7.08 $(\mathrm{m}, 4 \mathrm{H}), 6.92-6.88(\mathrm{~m}, 2 \mathrm{H}), 6.78-6.74(\mathrm{~m}, 2 \mathrm{H}), 6.64-6.60(\mathrm{~m}, 4 \mathrm{H}), 3.77(\mathrm{~s}, 3 \mathrm{H}) ;{ }^{13} \mathrm{C}$ NMR $(150$ $\left.\mathrm{MHz}, \mathrm{MeOD}-d_{4}\right) \delta 200.7,165.2(2 \mathrm{C}), 158.8,157.9$ (2C), 143.1, $142.4(2 \mathrm{C}), 137.5,133.2(2 \mathrm{C})$, 133.1, 132.7, 132.6, 131.5 (4C), 129.3 (2C), 127.6 (2C), 116.8 (2C), 115.9 (4C), 114.5 (2C), 56.0; HRMS (ESI) calculated for $\mathrm{C}_{32} \mathrm{H}_{25} \mathrm{O}_{5}(\mathrm{M}+\mathrm{H})$ : 489.1697; found 489.1697.

3.2.5. Synthesis of $\left(4,4^{\prime \prime}\right.$-dihydroxy-5'-(4-hydroxyphenyl)-[1, $1^{\prime}: 3^{\prime}, 1^{\prime \prime}$-terphenyl]-4'-yl)(4hydroxyphenyl)methanone-selagibenzophenone A (1)

Procedure A: A solution of (4,4' -dihydroxy-5'-(4-hydroxyphenyl)-[1,1':3', $1^{\prime \prime}$-terphenyl]$4^{\prime}$-yl)(4-methoxyphenyl)methanone 13 (0.01 mmol, $\left.5 \mathrm{mg}\right)$ and NaSEt $(0.24 \mathrm{mmol}, 20 \mathrm{mmol})$ in DMF $\left(0.8 \mathrm{~mL}\right.$, anhydrous) was heated in a vial at $100^{\circ} \mathrm{C}$. After $10 \mathrm{~h}$, the reaction mixture was cooled down and diluted with an aqueous $\mathrm{HCl}(1 \mathrm{M}, 8 \mathrm{~mL})$. The product was extracted with EA $(3 \times 10 \mathrm{~mL})$. Combined organic phases were dried over $\mathrm{Na}_{2} \mathrm{SO}_{4}$, filtered, and concentrated under reduced vacuum. The product was purified by preparative TLC with EA:Hex $(1: 2 \times 3)$. The reaction yielded $2 \mathrm{mg}(42 \%)$ of product in the form of an off-white glassy oil.

Procedure B: A solution of (4,4' -dimethoxy-5'-(4-methoxyphenyl)-[1,1': $3^{\prime}, 1^{\prime \prime}$-terphenyl]$4^{\prime}$-yl)(4-methoxyphenyl)methanone $14(0.038 \mathrm{mmol}, 20 \mathrm{mg})$ and NaSEt (0.667 mmol, $\left.56 \mathrm{mg}\right)$ in DMF was loaded into a vial, closed, and heated at $100{ }^{\circ} \mathrm{C}$. After $18 \mathrm{~h}$, the reaction mixture was cooled down and diluted with $\mathrm{HCl}$ solution $(1 \mathrm{M}, 15 \mathrm{~mL})$. The product was extracted with EA $(3 \times 20 \mathrm{~mL})$. Organic phases were washed with brine $(1 \times 4 \mathrm{~mL})$, dried over $\mathrm{Na}_{2} \mathrm{SO}_{4}$, filtered, and concentrated. The product was purified using column chromatography (EA:Hex, 1:4 to 2:1). The reaction yielded $8 \mathrm{mg}$ (44\%) of product in the form of an off-white glassy oil.

Procedure C: Olah's reagent (HF.pyridine, $12 \mathrm{mmol}, 0.3 \mathrm{~mL})$ was added to a solution of $\left(4,4^{\prime \prime}\right.$-bis((tert-butyldimethylsilyl)oxy)-5'-(4-((tert-butyldimethylsilyl)oxy)phenyl)-[1, $1^{\prime}: 3^{\prime}, 1^{\prime \prime}$ terphenyl]-4'-yl)(4-((tert-butyldimethylsilyl)oxy)phenyl)methanone (19) (0.02 mmol, $20 \mathrm{mg})$ in THF ( $5 \mathrm{~mL}$ ) in a plastic flask and stirred at $22{ }^{\circ} \mathrm{C}$ for $2 \mathrm{~h}$. Then, the reaction mixture was quenched with saturated solution $\mathrm{NaHCO}_{3}(5 \mathrm{~mL})$ and extracted with $\mathrm{EA}(3 \times 10 \mathrm{~mL})$. Combined organic layers were washed with $\mathrm{HCl}(1 \mathrm{M}, 1 \times 20 \mathrm{~mL})$, dried over $\mathrm{Na}_{2} \mathrm{SO}_{4}$, filtrated, and concentrated under reduced pressure. The selagibenzophenone A (1) was purified with column chromatography (DCM:MeOH 20:1). The reaction yielded $8.4 \mathrm{mg}$ $(82 \%)$ of product in the form of a slightly yellow solid. $\mathrm{R}_{f}=0.1$ [1:1 (EA:Hex)]; ${ }^{1} \mathrm{H}$ NMR $\left(600 \mathrm{MHz}, \mathrm{MeOD}-d_{4}\right) \delta$ 7.60-7.56 (m, 2H), $7.50(\mathrm{~s}, 2 \mathrm{H}), 7.43-7.39(\mathrm{~m}, 2 \mathrm{H}), 7.12-7.09(\mathrm{~m}, 4 \mathrm{H})$, 6.92-6.88 (m, 2H), 6.65-6.62 (m, 4H), 6.61-6.58 (m, 2H); $\left.{ }^{13} \mathrm{C} \mathrm{NMR} \mathrm{(150} \mathrm{MHz,} \mathrm{MeOD-d}\right) \delta$ 200.7, 163.8, 158.8, 157.9 (2C), 143.0, 142.4 (2C), 137.6, 133.5 (2C), 133.2 (2C), 132.8, 131.6, $131.5(4 \mathrm{C}), 129.3(2 \mathrm{C}), 127.6(2 \mathrm{C}), 116.8(2 \mathrm{C}), 116.0(2 \mathrm{C}), 115.8(4 \mathrm{C})$. The recorded values are in a good agreement with the published data [2].

\subsubsection{Synthesis of (4-bromophenoxy)(tert-butyl)dimethylsilane (16)}

Tert-butyl dimethyl silyl chloride (104 mmol, $16 \mathrm{~g}$ ) and imidazole (104 mmol, $7.5 \mathrm{~g})$ were added to a solution of a 4-bromophenol $15(87 \mathrm{mmol}, 15.5 \mathrm{~g})$ in DCM $(80 \mathrm{~mL})$ at $0{ }^{\circ} \mathrm{C}$. After 16 hours of stirring at $22{ }^{\circ} \mathrm{C}$, the reaction mixture was filtered through a short pad of silica gel and washed with hexanes $(200 \mathrm{~mL})$. The product was used in the next reaction without additional purification. The reaction yielded $22.5 \mathrm{~g}(91 \%)$ of product in the form of a transparent oil. $\mathrm{R}_{f}=0.4$ [Hex]; ${ }^{1} \mathrm{H} \mathrm{NMR}\left(400 \mathrm{MHz}, \mathrm{CDCl}_{3}\right) \delta 7.37-7.34(\mathrm{~m}, 2 \mathrm{H}), 6.77-6.74$ $(\mathrm{m}, 2 \mathrm{H}), 1.03(\mathrm{~s}, 9 \mathrm{H}), 0.23(\mathrm{~s}, 6 \mathrm{H}) .{ }^{13} \mathrm{C} \mathrm{NMR}\left(100 \mathrm{MHz}, \mathrm{CDCl}_{3}\right) \delta 155.0,132.4(2 \mathrm{C}), 122.0$ $(2 \mathrm{C}), 113.8,25.8(3 \mathrm{C}), 18.3,-4.4(2 \mathrm{C})$. The recorded values are in good agreement with the published data [26].

\subsubsection{Synthesis of (4-((tert-butyldimethylsilyl)oxy)phenyl)boronic acid (17)}

A solution of $n$-BuLi (1.6 M in hexane, $3.8 \mathrm{mmol}, 2.4 \mathrm{~mL})$ was slowly added to a solution of (4-bromophenoxy)(tert-butyl)dimethylsilane (16) (3.5 mmol, $1 \mathrm{~g}$ ) in THF $(10 \mathrm{~mL})$ at $-78{ }^{\circ} \mathrm{C}$. After $30 \mathrm{~min}$, triisopropyl borate $(10.5 \mathrm{mmol}, 2.3 \mathrm{~mL})$ was added in 
a dropwise manner at $-78{ }^{\circ} \mathrm{C}$ and the reaction was then allowed to warm to $22{ }^{\circ} \mathrm{C}$ and stirred for $16 \mathrm{~h}$. The reaction mixture was acidified with $\mathrm{HCl}(1 \mathrm{M}, 3 \mathrm{~mL})$. Then, the organic layer was washed with brine $(1 \times 5 \mathrm{~mL})$, dried over $\mathrm{Na}_{2} \mathrm{SO}_{4}$, filtered, and concentrated under reduced pressure. The product was purified with column chromatography (DCM to DCM:MeOH 20:1). The reaction yielded $700 \mathrm{mg}(80 \%)$ of product in the form of an off-white solid. ${ }^{1} \mathrm{H}$ NMR $\left(400 \mathrm{MHz}, \mathrm{CDCl}_{3}\right) \delta 8.13-8.11(\mathrm{~m}, 2 \mathrm{H}), 6.97-6.95(\mathrm{~m}, 2 \mathrm{H}), 1.02(\mathrm{~s}$, 9H), 0.26 (s, 6H). ${ }^{13} \mathrm{C} \mathrm{NMR}\left(100 \mathrm{MHz}, \mathrm{CDCl}_{3}\right) \delta 159.9,137.6$ (2C), 123.1, 119.9 (2C), 25.9 (3C), $18.5,-4.2(2 \mathrm{C})$. The recorded values are in good agreement with the published data [26].

3.2.8. Synthesis of 4,4"-bis((tert-butyldimethylsilyl)oxy)-5'-(4-((tert-butyldimethylsilyl) oxy)phenyl)-[1, $1^{\prime}: 3^{\prime}, 1^{\prime \prime}$-terphenyl]-2'-carbaldehyde (18)

2,4,6-Tribromobenzaldehyde 6 (0.29 mmol, $100 \mathrm{mg}), \mathrm{Pd}\left(\mathrm{PPh}_{3}\right)_{4}(0.029 \mathrm{mmol}, 10 \mathrm{~mol} \%$, $34 \mathrm{mg}), \mathrm{K}_{2} \mathrm{CO}_{3}(1.02 \mathrm{mmol}, 140 \mathrm{mg})$, and (4-methoxyphenyl)boronic acid 9 (0.92 mmol, $140 \mathrm{mg}$ ) were dissolved in a degassed mixture of benzene and $\mathrm{H}_{2} \mathrm{O}(5: 1,2.2 \mathrm{~mL})$. The reaction was heated in a closed vial at $90{ }^{\circ} \mathrm{C}$ for $16 \mathrm{~h}$. Then, the reaction mixture was concentrated and the product was purified with column chromatography (EA:Hex 1:20 to 1:4). The reaction yielded $166 \mathrm{mg}(79 \%)$ of product in the form of a yellow glassy oil. $\mathrm{R}_{f}=0.14$ [EA:Hex (1:30)]; IR (KBr) 3033, 2956, 2858, 2540, 1699, 1604, 1508, 1263, 914, 837, $781 \mathrm{~cm}^{-1} ;{ }^{1} \mathrm{H}$ NMR $\left(400 \mathrm{MHz}, \mathrm{CDCl}_{3}\right) \delta 9.96(\mathrm{~s}, 1 \mathrm{H}), 7.57(\mathrm{~d}, J=8.6 \mathrm{~Hz}, 2 \mathrm{H}), 7.52(\mathrm{~s}, 2 \mathrm{H})$, 7.30-7.22 (m, 4H), 6.96-6.86 (m, 6H), $1.02(\mathrm{~s}, 18 \mathrm{H}), 1.00(\mathrm{~s}, 9 \mathrm{H}), 0.25(\mathrm{~s}, 12 \mathrm{H}), 0.23(\mathrm{~s}, 6 \mathrm{H})$; ${ }^{13} \mathrm{C}$ NMR $\left(100 \mathrm{MHz}, \mathrm{CDCl}_{3}\right) \delta 193.5,156.4,155.6$ (2C), 145.1 (2C), 143.8, 132.9 (2C), 132.7, 131.3, 130.9 (4C), 128.6 (2C), 128.4 (2C), 120.7 (2C), 119.8 (4C), 25.8 (9C), 18.4 (3C), -4.2 (6C); HRMS (ESI) calculated for $\mathrm{C}_{43} \mathrm{H}_{61} \mathrm{O}_{4} \mathrm{Si}_{3}\left(\mathrm{MS}+\mathrm{H}^{+}\right.$): 725.3872; found 725.3895.

3.2.9. Synthesis of (4,4'-bis((tert-butyldimethylsilyl)oxy)-5'-(4-((tert-butyldimethylsilyl)oxy) phenyl)-[1,1':3',1'-terphenyl]-4'-yl)(4-((tert-butyldimethylsilyl)oxy)phenyl)methanone (19)

A solution of $t$-BuLi (1.7 M in heptane, $0.25 \mathrm{mmol}, 0.16 \mathrm{~mL})$ was added in a dropwise manner to a solution of (4-bromophenoxy)(tert-butyl)dimethylsilane $(\mathbf{1 6}, 0.25 \mathrm{mmol}, 70 \mathrm{mg})$ in THF ( $3 \mathrm{~mL})$ at $-78^{\circ} \mathrm{C}$. After $20 \mathrm{~min}$, a solution of $4,4^{\prime \prime}$-bis((tert-butyldimethylsilyl)oxy)$5^{\prime}$-(4-((tert-butyldimethylsilyl)oxy)phenyl)-[1,1': $3^{\prime}, 1^{\prime \prime}$-terphenyl]-2'-carbaldehyde (18, 0.18 mmol, $130 \mathrm{mg})$ in THF $(3 \mathrm{~mL})$ was added and the reaction was stirred at $-78{ }^{\circ} \mathrm{C}$ for $1 \mathrm{~h}$. The reaction mixture was warmed up to room temperature, quenched with water $(10 \mathrm{~mL})$, and extracted with EA $(3 \times 20 \mathrm{~mL})$. Combined organic layers were dried over $\mathrm{MgSO}_{4}$, filtered, and concentrated. The resulting crude product was redissolved in DCM $(10 \mathrm{~mL})$ and Celite ${ }^{\circledR}(200 \mathrm{mg})$ and PCC $(0.4 \mathrm{mmol}, 90 \mathrm{mg})$ was added to it. After $16 \mathrm{~h}$, the reaction mixture was filtered through a pad of Celite ${ }^{\circledR}$. The product was purified with column chromatography (DCM:Hex, 1:3 to 1:1). The reaction yielded $96 \mathrm{mg}(57 \%)$ of product in the form of a yellow oil. $\mathrm{R}_{f}=0.2$ [DCM:Hex (1:2)]; IR (KBr) 2966, 2929, 2887, 2858, 1666, 1597, $1508,1263 \mathrm{~cm}^{-1} ;{ }^{1} \mathrm{H}$ NMR $\left(400 \mathrm{MHz}, \mathrm{CD}_{3} \mathrm{OD}\right) 7.59-7.57(\mathrm{~m}, 2 \mathrm{H}), 7.55(\mathrm{~s}, 2 \mathrm{H}), 7.44-7.42(\mathrm{~m}$, $2 \mathrm{H}), 7.17-7.15(\mathrm{~m}, 4 \mathrm{H}), 6.94-6.92(\mathrm{~m}, 2 \mathrm{H}), 6.68-6.66(\mathrm{~m}, 4 \mathrm{H}), 6.59-6.57(\mathrm{~m}, 2 \mathrm{H}), 1.01(\mathrm{~s}, 9 \mathrm{H})$, $0.94(\mathrm{~s}, 27 \mathrm{H}), 0.24(\mathrm{~s}, 6 \mathrm{H}), 0.16(\mathrm{~s}, 6 \mathrm{H}), 0.13(\mathrm{~s}, 12 \mathrm{H}) .{ }^{13} \mathrm{C}$ NMR $\left(100 \mathrm{MHz}, \mathrm{CD}_{3} \mathrm{OD}\right) \delta 197.9$, 159.8, 155.9, 155.1 (2C), 141.3, 141.1 (2C), 136.9, 133.8 (2C), 133.5, 132.4, 131.7 (2C), 130.5 (4C), $128.4(2 \mathrm{C}), 127.2(2 \mathrm{C}), 120.6(2 \mathrm{C}), 119.8(4 \mathrm{C}), 119.4(2 \mathrm{C}), 25.9(3 \mathrm{C}), 25.8(6 \mathrm{C}), 25.7(3 \mathrm{C})$, $18.4,18.3(3 \mathrm{C}),-4.2(2 \mathrm{C}),-4.3(2 \mathrm{C}),-4.3(4 \mathrm{C})$; HRMS (ESI) calculated for $\mathrm{C}_{55} \mathrm{H}_{78} \mathrm{O}_{5} \mathrm{Si}_{4}$ $\left(\mathrm{MS}+\mathrm{H}^{+}\right.$): 931.4999; found 931.5030.

\subsubsection{Synthesis of Methyl 3,4,5-tris(((trifluoromethyl)sulfonyl)oxy)benzoate (20)}

In a flame-dried flask, methyl gallate $\left(7.6 \mathrm{mmol}, 1.5 \mathrm{~g}\right.$ ) was dissolved in $\mathrm{CH}_{2} \mathrm{Cl}_{2}$ $(20 \mathrm{~mL})$ under an inert atmosphere. Triethyl amine $(24.2 \mathrm{mmol}, 3.4 \mathrm{~mL})$ was added, whereupon the suspension dissolved. The mixture was cooled to $0{ }^{\circ} \mathrm{C}$ and $\mathrm{Tf}_{2} \mathrm{O}(24.2$ $\mathrm{mmol}, 4.07 \mathrm{~mL}$ ) was added. The mixture was heated to the room temperature and stirred for 5 minutes. After this, the reaction was quenched via the addition of $5 \% \mathrm{HCl}(20 \mathrm{~mL})$. The organic phase was separated and washed with $\mathrm{NaHCO}_{3}(15 \mathrm{~mL})$ and brine $(15 \mathrm{~mL})$. The organic phase was dried with $\mathrm{MgSO}_{4}$ and concentrated under reduced pressure. The 
mixture was used without further purification for the next step. $R_{f}=0.3$ [EA:Hex (1:10)]; $\mathrm{mp}=49-51^{\circ} \mathrm{C}(\mathrm{DCM}) ; \mathrm{IR}(\mathrm{KBr}) 3116,2968,2682,2355,1728,1597,1435,1321 \mathrm{~cm}^{-1} ;{ }^{1} \mathrm{H}$ NMR (300 MHz, CDCl $) \delta 8.20(\mathrm{~s}, 2 \mathrm{H}), 4.02(\mathrm{~s}, 3 \mathrm{H}) ;{ }^{13} \mathrm{C} \mathrm{NMR}\left(75 \mathrm{MHz}, \mathrm{CDCl}_{3}\right) \delta 162.7$, 142.4, 132.1, 125.1, 124.1, 120.8, 120.7, 116.6, 116.4, 112.3, 53.8; HRMS (ESI) calculated for $\mathrm{C}_{11} \mathrm{H}_{9} \mathrm{~F}_{9} \mathrm{NO}_{11} \mathrm{~S}_{3}\left(\mathrm{MS}+\mathrm{NH}_{4}^{+}\right): 597.9198$; found 597.9192.

3.2.11. Synthesis of Methyl 4,4"'-dimethoxy-6'-(4-methoxyphenyl)-[1, $1^{\prime}: 2^{\prime}, 1^{\prime \prime}$-terphenyl]$4^{\prime}$-carboxylate (21)

Aldehyde 20 (2.60 mmol, $1.49 \mathrm{mg}), \mathrm{Pd}\left(\mathrm{PPh}_{3}\right)_{4}(0.26 \mathrm{mmol}, 10 \mathrm{~mol} \%, 300 \mathrm{mg}), \mathrm{K}_{2} \mathrm{CO}_{3}$ (9.1 mmol, $1.25 \mathrm{mg})$, and (4-methoxyphenyl)boronic acid $9(8.20 \mathrm{mmol}, 1.24 \mathrm{mg})$ were dissolved in a degassed mixture of benzene and $\mathrm{H}_{2} \mathrm{O}(5: 1,20 \mathrm{~mL})$. The reaction was heated in a closed vial at $90{ }^{\circ} \mathrm{C}$ for $16 \mathrm{~h}$. Then, the reaction mixture was concentrated and the product was purified with column chromatography (EA:Hex 1:99 to 1:10). The reaction yielded $865 \mathrm{mg}(71 \%)$ of product in the form of a yellow glassy oil. $\mathrm{R}_{f}=0.15$ [EA:Hex (1:4)]; $\mathrm{mp}=133-136^{\circ} \mathrm{C}(\mathrm{DCM}) ; \mathrm{IR}(\mathrm{KBr}) 3066,3005,2993,2935,2839,2065,1716,1608,1514$, $1435 \mathrm{~cm}^{-1} ;{ }^{1} \mathrm{H}$ NMR $\left(400 \mathrm{MHz}, \mathrm{CDCl}_{3}\right) \delta 8.04(\mathrm{~s}, 2 \mathrm{H}), 7.03-6.96(\mathrm{~m}, 4 \mathrm{H}), 6.80-6.68(\mathrm{~m}, 6 \mathrm{H})$, 6.61-6.54 (m, 2H), $3.94(\mathrm{~s}, 3 \mathrm{H}), 3.76(\mathrm{~s}, 6 \mathrm{H}), 3.70(\mathrm{~s}, 3 \mathrm{H}) ;{ }^{13} \mathrm{C} \mathrm{NMR}\left(100 \mathrm{MHz}, \mathrm{CDCl}_{3}\right) \delta 167.2$, 158.3 (2C), 158.0, 143.4, 142.2, 133.8, 132.5 (2C), 131.4, 131.0 (4C), 130.4 (2C), 128.8, 113.3 (4C), 113.1 (2C), 55.3, 55.1, 52.3; HRMS (ESI) calculated for $\mathrm{C}_{29} \mathrm{H}_{27} \mathrm{O}_{5}\left(\mathrm{MS}+\mathrm{H}^{+}\right.$): 455.1853 ; found 455.1853 .

3.2.12. Synthesis of $4,4^{\prime \prime}$-dimethoxy-6'-(4-methoxyphenyl)-[1, $1^{\prime}: 2^{\prime}, 1^{\prime \prime}$-terphenyl]-4'carbaldehyde (22)

A solution of $\mathrm{LiAlH}_{4}(1 \mathrm{M}$ in THF, $1.6 \mathrm{mmol}, 1.6 \mathrm{~mL})$ was added dropwise into a solu-

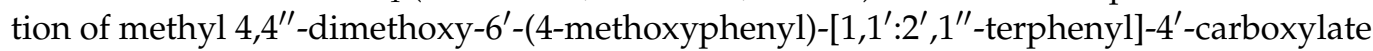
(21) $(0.82 \mathrm{mmol}, 400 \mathrm{mg})$ in THF $(10 \mathrm{~mL})$ at $0{ }^{\circ} \mathrm{C}$. After $1 \mathrm{~h}$, the reaction mixture was quenched with $\mathrm{Na}_{2} \mathrm{SO}_{4}$ (300 mg), filtered through a pad of Celite ${ }^{\circledR}$, then the filtrate was concentrated under reduced pressure. The crude mixture was then dissolved in DCM $(10 \mathrm{~mL})$. After adding Celite ${ }^{\circledR}(400 \mathrm{mg})$ and PCC $(1.6 \mathrm{mmol}, 356 \mathrm{mg})$, the reaction mixture was left to stir for $16 \mathrm{~h}$. Then, it was filtered through a plug of Celite ${ }^{\circledR}$, the filtrate was concentrated, and the product was purified with column chromatography (EA:Hex 1:5). The reaction yielded $270 \mathrm{mg}(72 \%)$ of product in the form of a yellow glassy oil. $\mathrm{R}_{f}=0.2$ [EA:Hex (1:4)]; IR (KBr) 3032, 2999, 2956, 2933, 2835, 2729, 2536, 2044, 1888, 1695, 1512, $1441 \mathrm{~cm}^{-1} ;{ }^{1} \mathrm{H}$ NMR $\left(400 \mathrm{MHz}, \mathrm{CDCl}_{3}\right) \delta 10.09(\mathrm{~s}, 1 \mathrm{H}), 7.86(\mathrm{~s}, 2 \mathrm{H}), 7.00-6.98(\mathrm{~m}, 4 \mathrm{H})$, 6.74-6.72 (m, 6H) 6.59-6.57 (m, 2H), $3.77(\mathrm{~s}, 6 \mathrm{H}), 3.71(\mathrm{~s}, 3 \mathrm{H}) ;{ }^{13} \mathrm{C} \mathrm{NMR}\left(100 \mathrm{MHz}, \mathrm{CDCl}_{3}\right) \delta$ 192.3, 158.5 (2C), 158.2, 145.1, 142.9 (2C), 135.2, 133.5 (2C), 132.4 (2C), 131.2, 130.9 (4C), 130.6 (2C), $113.4(4 \mathrm{C}), 113.2(2 \mathrm{C}), 55.3(2 \mathrm{C}), 55.2$; HRMS (ESI) calculated for $\mathrm{C}_{28} \mathrm{H}_{25} \mathrm{O}_{4}\left(\mathrm{MS}+\mathrm{H}^{+}\right.$): 425.1747; found 425.1749.

3.2.13. Synthesis of $\left(4,4^{\prime \prime}\right.$-dimethoxy-6'-(4-methoxyphenyl)-[1, $1^{\prime}: 2^{\prime}, 1^{\prime \prime}$-terphenyl]-4'-yl)(4methoxyphenyl)methanone) (23)

A solution of (4-methoxyphenyl)magnesium bromide (1M in THF, $1 \mathrm{~mL}, 1 \mathrm{mmol}$ ) was added in a dropwise manner to a solution of 4,4'-dimethoxy-6'-(4-methoxyphenyl)$\left[1,1^{\prime}: 2^{\prime}, 1^{\prime \prime}\right.$-terphenyl]- $4^{\prime}$-carbaldehyde $(\mathbf{2 2}, 0.64 \mathrm{mmol}, 270 \mathrm{mg})$ in THF $(10 \mathrm{~mL})$ at $0{ }^{\circ} \mathrm{C}$. After $16 \mathrm{~h}$, the reaction was quenched with a saturated solution of $\mathrm{NH}_{4} \mathrm{Cl}(20 \mathrm{~mL})$ and extracted with EA $(3 \times 30 \mathrm{~mL})$. The combined organic phases were dried over $\mathrm{Na}_{2} \mathrm{SO}_{4}$, filtered, and evaporated. The crude mixture was then dissolved in DCM $(20 \mathrm{~mL})$ and Celite ${ }^{\circledR}(240 \mathrm{mg})$ and PCC $(0.9 \mathrm{mmol}, 196 \mathrm{mg})$ was added to it. After $16 \mathrm{~h}$, the reaction mixture was filtered over a Celite ${ }^{\circledR}$ pad and the filtrate was concentrated. The product was purified with column chromatography (EA:Hex 1:10 to 4:1). The reaction yielded $141 \mathrm{mg}(70 \%)$ of product in the form of a slightly yellow solid. $\mathrm{R}_{f}=0.2$ [EA:Hex (1:5)]; $\mathrm{mp}=77-78^{\circ} \mathrm{C}(\mathrm{DCM}) ; \mathrm{IR}(\mathrm{KBr})$ 3032, 3001, 2956, 2931, 2908, 2835, 1510, 1250, 1034, $831 \mathrm{~cm}^{-1}$; ${ }^{1} \mathrm{H}$ NMR $\left(400 \mathrm{MHz}, \mathrm{CDCl}_{3}\right)$ 反 7.95-7.93 (m, 2H), $7.75(\mathrm{~s}, 2 \mathrm{H}), 7.01-6.97(\mathrm{~m}, 6 \mathrm{H}), 6.77-6.70(\mathrm{~m}, 2 \mathrm{H}), 6.72-6.70(\mathrm{~m}, 4 \mathrm{H})$, 6.60-6.57 (m, 2H), $3.89(\mathrm{~s}, 3 \mathrm{H}), 3.76(\mathrm{~s}, 3 \mathrm{H}), 3.72(\mathrm{~s}, 3 \mathrm{H}) ;{ }^{13} \mathrm{C} \mathrm{NMR}\left(100 \mathrm{MHz}, \mathrm{CDCl}_{3}\right) \delta$ 198.4, 
$163.4,158.3$ (2C), 158.1, 142.4, 141.9 (2C), 137.1, 133.9 (2C), 132.7 (2C), $132.6(2 \mathrm{C}), 131.5,131.1$ (4C), 130.7 (2C), 130.4, 113.8 (2C), 113.3 (4C), 113.1 (2C), 55.6, 55.3(2C), 55.2; HRMS (ESI) calculated for $\mathrm{C}_{35} \mathrm{H}_{31} \mathrm{O}_{5}\left(\mathrm{MS}+\mathrm{H}^{+}\right)$: 531.2166; found 531.2161.

3.2.14. Synthesis of $\left(4,4^{\prime \prime}\right.$-dihydroxy-6 $6^{\prime}$-(4-hydroxyphenyl)-[1, $1^{\prime}: 2^{\prime}, 1^{\prime \prime}$-terphenyl $]-4^{\prime}$-yl)(4hydroxyphenyl)methanone-selagibenzophenone B (2)

A solution of $\mathrm{a} \mathrm{BBr}_{3}(1 \mathrm{M}$ in heptane, $0.2 \mathrm{mmol}, 0.2 \mathrm{ml})$ was added in a dropwise manner to a solution of the $\left(4,4^{\prime \prime}\right.$-dimethoxy-6 $6^{\prime}$-(4-methoxyphenyl)-[1,1': $2^{\prime}, 1^{\prime \prime}$-terphenyl]- $4^{\prime}$ yl)(4-methoxyphenyl)methanone $(\mathbf{2 3}, 0.026 \mathrm{mmol}, 14 \mathrm{mg})$ in DCM (2 mL) at room temperature. After $16 \mathrm{~h}$, the reaction was quenched with a saturated solution of $\mathrm{NH}_{4} \mathrm{Cl}(5 \mathrm{~mL})$ and extracted with EA $(3 \times 10 \mathrm{~mL})$. Combined organic phases were dried over $\mathrm{Na}_{2} \mathrm{SO}_{4}$, filtered, and evaporated. The product was purified with preparative TLC (DCM:MeOH, 20:1). The reaction yielded $6 \mathrm{mg}$ of the monomethoxy derivative $\left(4,4^{\prime \prime}\right.$-dihydroxy- $6^{\prime}-(4-$ hydroxyphenyl)-[1,1':2' $1^{\prime \prime}$-terphenyl $]-4^{\prime}$-yl)(4-methoxyphenyl)methanone (48\% yield) and $6 \mathrm{mg}$ of the selagibenzophenone B (2) in the form yellow solids (36\% yield). Selagibenzophenone B (2): $\mathrm{R}_{f}=0.2$ [DCM:MeOH 20:1]; $\mathrm{mp}=250{ }^{\circ} \mathrm{C}$ (decomp.); IR (KBr) 3459, 2927, 2792, 1587, $1342 \mathrm{~cm}^{-1} ;{ }^{1} \mathrm{H}$ NMR (600 MHz, MeOD-d $) \delta 7.79-7.55(\mathrm{~m}, 2 \mathrm{H}), 7.58$ (s, 2H), 6.93-6.88 (m, 4H), 6.77-6.74 (m, 2H), 6.77-6.74 (m, 2H), 6.61-6.58 (m, 4H), 6.50-6.46 (m, $2 \mathrm{H}) ;{ }^{13} \mathrm{C}$ NMR $\left(150 \mathrm{MHz}, \mathrm{MeOD}-d_{4}\right) \delta 197.5,170.5,157.2$ (2C), 156.9, 143.7, $143.4(2 \mathrm{C}), 138.8$, $134.6(2 \mathrm{C}), 134.2,133.7(2 \mathrm{C}), 132.1$ (4C), 131.9, $131.0(2 \mathrm{C}), 126.5,118.2(2 \mathrm{C}), 115.6(4 \mathrm{C}), 115.4$ (2C). HRMS (ESI) calculated for $\mathrm{C}_{31} \mathrm{H}_{23} \mathrm{O}_{5}\left(\mathrm{MS}+\mathrm{H}^{+}\right)$: 475.1540, found 475.1545.

3.2.15. Synthesis of $\left(4,4^{\prime \prime}\right.$-dihydroxy-6 $6^{\prime}$-(4-hydroxyphenyl)-[1, $1^{\prime}: 2^{\prime}, 1^{\prime \prime}$-terphenyl]-4'-yl)(4methoxyphenyl)methanone-(monomethoxy-selagibenzophenone B) (24)

$\mathrm{R}_{f}=0.4$ [DCM:MeOH 20:1]; $\mathrm{mp}=253-254^{\circ} \mathrm{C}(\mathrm{DCM}) ; \mathrm{IR}(\mathrm{KBr}) 3302,3032,2958,2841$, $1888,1699,1595,1512,1419,1342,1257 \mathrm{~cm}^{-1} ;{ }^{1} \mathrm{H}$ NMR $\left(400 \mathrm{MHz}, \mathrm{CD}_{3} \mathrm{OD}\right) \delta 7.90-7.88$ $(\mathrm{m}, 2 \mathrm{H}), 7.62(\mathrm{~s}, 2 \mathrm{H}), 7.07-7.05(\mathrm{~m}, 2 \mathrm{H}), 6.90-6.88(\mathrm{~m}, 4 \mathrm{H}), 6.66-6.64(\mathrm{~m}, 2 \mathrm{H}), 6.60-6.58(\mathrm{~m}$, $4 \mathrm{H}), 6.49-6.47(\mathrm{~m}, 2 \mathrm{H}), 3.89(\mathrm{~s}, 3 \mathrm{H}) ;{ }^{13} \mathrm{C} \mathrm{NMR}\left(100 \mathrm{MHz}, \mathrm{CD}_{3} \mathrm{OD}\right) \delta 197.5,165.2,157.2$ (2C), 156.9, 144.4, 143.7 (2C), 137.8, 134.0, 133.7 (3C), 133.7 (2C), 132.0 (4C), 131.7, 131.3 (2C), 131.2, 115.6 (4C), 115.4 (2C), 114.9 (2C), 56.1; HRMS (ESI) calculated for $\mathrm{C}_{32} \mathrm{H}_{25} \mathrm{O}_{5}(\mathrm{MS}+$ $\left.\mathrm{H}^{+}\right)$: 489.1697 found 489.1691 .

\section{Conclusions}

In conclusion, we accomplished the total synthesis of the natural product selagibenzophenone A (1), comprising a Suzuki coupling and an addition of an organometallic aromatic compound to a carbonyl moiety to assemble the backbone of the natural product. Further adjustment of the oxidation state and liberation of the phenols led to the synthesis of selagibenzophenone A (1) and to confirmation of the proposed structure. The synthesis was performed using two different protecting group strategies. In the first, the phenols were protected as methoxy groups and partial control over the selectivity of the deprotection was gained, depending on the deprotection method used. This will be useful in the future synthesis of derivatives of the natural product and determination of the structureactivity relationship. However, the protocol leading to the formation of the desired natural product lacked reproducibility, which prompted us to develop a second-generation synthesis procedure, using easily removable TBS protecting groups. This approach allowed us to achieve the first reliable total synthesis of selagibenzophenone A (1).

In addition, we achieved the total synthesis of compound 2, which had been described as a natural product known as selagibenzophenone B by $\mathrm{Xu}$ and Tan [3] and by Liang and Wang [4]. Our synthetic studies and comparison of our data with previously reported data revealed that the structure of the isolated material, described as selagibenzophenone B, is in fact misassigned and that the isolated compound is selagibenzophenone A. This finding is important not only for natural product chemists but also for the medicinal chemistry community because several biological activities have been reported for selagibenzophenone B (2) when they should be instead ascribed to selagibenzophenone A (1). 
Currently, follow-up studies are being conducted in our laboratory and in the laboratories of our collaborators, where natural and unnatural selagibenzophenones are being prepared and assessed for their biological effects.

Supplementary Materials: The following are available online at https:/ /www.mdpi.com/article/10 .3390/catal11060708/s1: Figure S1: Numbering of selagibenzophenones A and B and key HMBC correlations for selagibenzophenone B; Table S1: Comparison of NMR shifts of synthetic and isolated selagibenzophenones A and B; Figure S2: ${ }^{1} \mathrm{H}$ NMR spectra of compound 10 in $\mathrm{CDCl}_{3}(400 \mathrm{MHz})$; Figure S3: ${ }^{13} \mathrm{C}$ NMR spectra of compound 10 in $\mathrm{CDCl}_{3}(100 \mathrm{MHz})$; Figure S4: ${ }^{1} \mathrm{H}$ NMR spectra of compound 12 in $\mathrm{CDCl}_{3}(400 \mathrm{MHz})$; Figure S5: ${ }^{13} \mathrm{C}$ NMR spectra of compound 12 in $\mathrm{CDCl}_{3}(100 \mathrm{MHz})$; Figure S6: ${ }^{1} \mathrm{H}$ NMR spectra of compound 13 in $\mathrm{CDCl}_{3}(400 \mathrm{MHz})$; Figure S7: ${ }^{13} \mathrm{C}$ NMR spectra of compound 13 in $\mathrm{CDCl}_{3}(100 \mathrm{MHz})$; Figure S8: ${ }^{1} \mathrm{H}$ NMR spectra of compound 14 in MeOD- $d_{4}$ (600 MHz); Figure S9: ${ }^{13} \mathrm{C}$ NMR spectra of compound 14 in MeOD- $d_{4}(150 \mathrm{MHz})$; Figure S10: ${ }^{1} \mathrm{H}$ NMR spectra of selagibenzophenone A (1) in MeOD- $d_{4}(400 \mathrm{MHz})$; Figure S11: ${ }^{13} \mathrm{C}$ NMR spectra of selagibenzophenone A (1) in MeOD- $d_{4}(100 \mathrm{MHz})$; Figure S12: COSY spectra of selagibenzophenone A (1) in MeOD- $d_{4}$; Figure S13: HSQC spectra of selagibenzophenone A (1) in MeOD- $d_{4}$; Figure S 14: HSQC spectra of selagibenzophenone A (1) in MeOD- $d_{4}$; Figure S15: ${ }^{1} \mathrm{H}$ NMR spectra of compound 18 in $\mathrm{CDCl}_{3}$ (400 MHz); Figure S17: ${ }^{1} \mathrm{H}$ NMR spectra of compound 19 in $\mathrm{CDCl}_{3}(400 \mathrm{MHz})$; Figure S18: ${ }^{13} \mathrm{C}$ NMR spectra of compound 19 in $\mathrm{CDCl}_{3}(100 \mathrm{MHz})$; Figure S19: ${ }^{1} \mathrm{H}$ NMR spectra of compound 20 in $\mathrm{CDCl}_{3}(300 \mathrm{MHz})$; Figure S20: ${ }^{13} \mathrm{C}$ NMR spectra of compound 20 in $\mathrm{CDCl}_{3}(75 \mathrm{MHz})$; Figure S21: ${ }^{1} \mathrm{H}$ NMR spectra of compound 21 in $\mathrm{CDCl}_{3}(400 \mathrm{MHz})$; Figure S22: ${ }^{13} \mathrm{C}$ NMR spectra of compound 21 in $\mathrm{CDCl}_{3}(100 \mathrm{MHz})$; Figure S23: ${ }^{1} \mathrm{H}$ NMR spectra of compound 22 in $\mathrm{CDCl}_{3}(400 \mathrm{MHz})$; Figure S24: ${ }^{13} \mathrm{C}$ NMR spectra of compound 22 in $\mathrm{CDCl}_{3}(100 \mathrm{MHz})$; Figure S25: ${ }^{1} \mathrm{H}$ NMR spectra of compound 23 in $\mathrm{CDCl}_{3}$ (400 MHz); Figure S27: ${ }^{1} \mathrm{H}$ NMR spectra of selagibenzophenone B (2) in MeOD- $d_{4}$ (400 MHz); Figure S28: ${ }^{13} \mathrm{C}$ NMR spectra of selagibenzophenone B (2) in MeOD- $d_{4}(100 \mathrm{MHz})$; Figure S29: COSY spectra of selagibenzophenone B (2) in MeOD- $d_{4}$; Figure S30: HSQC spectra of selagibenzophenone B (2) in MeOD- $d_{4}$; Figure S31: HMBC spectra of selagibenzophenone B (2) in MeOD- $d_{4}$; Figure S32: ${ }^{1} \mathrm{H}$ NMR spectra of monomethoxy-selagibenzophenone B 24 in MeOD- $d_{4}$ (400 MHz); Figure S33: ${ }^{13} \mathrm{C}$ NMR spectra of monomethoxy-selagibenzophenone B 24 in MeOD$d_{4}(100 \mathrm{MHz})$; Figure S34: COSY spectra of monomethoxy-selagibenzophenone B 24 in MeOD- $d_{4}$ (100 MHz).

Author Contributions: Conceptualization, L.R.; methodology, R.L., Š.M., M.M.; resources, L.R.; writing—original draft preparation, L.R.; writing—review and editing, R.L.; supervision, L.R.; project administration, L.R.; funding acquisition, L.R. All authors have read and agreed to the published version of the manuscript.

Funding: This research was funded by Charles University Primus program grant number PRIMUS/20/SCI/ 017 and Charles University Research Center program grant number UNCE/SCI/014.

Data Availability Statement: The following data are available: primary NMR FID files for compounds: 1, 2, 10, 12, 13, 14, 15, 16, 17, 18, 19, 20, 21, 22, 23, and 24 .

Conflicts of Interest: The authors declare no conflict of interest. The funders had no role in the design of the study; in the collection, analyses, or interpretation of data; in the writing of the manuscript, or in the decision to publish the results.

\section{References}

1. Banks, J.A. Selaginella and 400 Million Years of Separation. Annu. Rev. Plant. Biol. 2009, 60, 223-238. [CrossRef] [PubMed]

2. Liu, X.; Tang, G.-H.; Weng, H.-Z.; Zhang, J.-Z.; Xu, Y.-K.; Yin, S. A new selaginellin derivative and a new triarylbenzophenone analog from the whole plant of Selaginella pulvinata. J. Asian Nat. Prod. Res. 2018, 20, 1123-1128. [CrossRef]

3. Liu, R.; Zou, H.; Zou, Y.-X.; Cheng, F.; Yu, X.; Xu, P.S.; Li, X.M.; Li, D.; Xu, K.-P.; Tan, G.-S. Two new anthraquinone derivatives and one new triarylbenzophenone analog from Selaginella tamariscina. Nat. Prod. Res. 2020, 34, 2709-2714. [CrossRef] [PubMed]

4. Wang, C.-G.; Yao, W.-N.; Zhang, B.; Hua, J.; Liang, D.; Wang, H.-S. Lung cancer and matrix metalloproteinases inhibitors of polyphenols from Selaginella tamariscina with suppression activity of migration. Bioorg. Med. Chem. Lett. 2018, 28, $2413-2417$. [CrossRef] [PubMed]

5. Liu, X.; Luo, H.-B.; Huang, Y.-Y.; Bao, J.-M.; Tang, G.-H.; Chen, Y.-Y.; Wang, J.; Yin, S. Selaginpulvilins A-D, New Phosphodiesterase-4 Inhibitors with an Unprecedented Skeleton from Selaginella pulvinata. Org. Lett. 2014, 16, 282-285. [CrossRef] 
6. Woo, S.; Kang, K.B.; Kim, J.; Sung, S.H. Molecular Networking Reveals the Chemical Diversity of Selaginellin Derivatives, Natural Phosphodiesterase-4 Inhibitors from Selaginella tamariscina. J. Nat. Prod. 2019, 82, 1820-1830. [CrossRef]

7. Li, W.; Tang, G.-H.; Yin, S. Selaginellins from the genus Selaginella: Isolation, structure, biological activity, and synthesis. Nat. Prod. Rep. 2020. [CrossRef]

8. Cao, Y.; Chen, J.-J.; Tan, N.-H.; Oberer, L.; Wagner, T.; Wu, J.-P.; Zeng, G.-Z.; Yan, H.; Wang, Q. Antimicrobial selaginellin derivatives from Selaginella pulvinata. Bioorg. Med. Chem. Lett. 2010, 20, 2456-2460. [CrossRef]

9. Zhang, G.-G.; Jing, Y.; Zhang, H.-M.; Ma, E.-I.; Guan, J.; Xue, F.-N.; Liu, H.-X.; Sun, X.-Y. Isolation and Cytotoxic Activity of Selaginellin Derivatives and Biflavonoids from Selaginella tamariscina. Planta Med. 2012, 78, 390-392. [CrossRef]

10. Nguyen, P.-H.; Zhao, B.-T.; Ali, M.Y.; Choi, J.-S.; Rhyu, D.-Y.; Min, B.-S.; Woo, M.-H. Insulin-Mimetic Selaginellins from Selaginella tamariscina with Protein Tyrosine Phosphatase 1B (PTP1B) Inhibitory Activity. J. Nat. Prod. 2015, 78, 34-42. [CrossRef]

11. Sengupta, S.; Mehta, G. Natural products as modulators of the cyclic-AMP pathway: Evaluation and synthesis of lead compounds. Org. Biomol. Chem. 2018, 16, 6372-6390. [CrossRef] [PubMed]

12. Karmakar, R.; Lee, D. Total Synthesis of Selaginpulvilin C and D Relying on in Situ Formation of Arynes and Their Hydrogenation. Org. Lett. 2016, 18, 6105-6107. [CrossRef]

13. Chinta, B.S.; Baire, B. Formal total synthesis of selaginpulvilin D. Org. Biomol. Chem. 2017, 15, 5908-5911. [CrossRef] [PubMed]

14. Chinta, B.S.; Baire, B. Total synthesis of selaginpulvilins A and C. Org. Biomol. Chem. 2018, 16, 262-265. [CrossRef]

15. Sowden, M.J.; Sherburn, M.S. Four-Step Total Synthesis of Selaginpulvilin D. Org. Lett. 2012, 19, 636-637. [CrossRef]

16. Zhang, J.-S.; Liu, X.; Weng, J.; Guo, Y.-Q.; Li, Q.-J.; Ahmed, A.; Tang, G.-H.; Yin, S. Natural diarylfluorene derivatives: Isolation, total synthesis, and phosphodiesterase-4 inhibition. Org. Chem. Front. 2017, 4, 170-177. [CrossRef]

17. Rycek, L.; Mateus, M.; Beytlerová, N.; Kotora, M. Catalytic Cyclotrimerization Pathway for Synthesis of Selaginpulvilins C and D: Scope and Limitations. Org. Lett. 2021. Ahead of Print. [CrossRef]

18. Press, N.J.; Banner, K.H. PDE4 Inhibitors-A Review of the Current Field. In Progress in Medicinal Chemistry; Lawton, G., Witty, D.R., Eds.; Elsevier B.V.: Amsterdam, The Netherlands, 2009; Volume 47, pp. 37-74.

19. Zhang, K.Z.J.; Ibrahim, P.N.; Gillette, S.; Bollag, G. Phosphodiesterase-4 as a potential drug target. Expert Opin. Ther. Targets 2005, 9, 1283-1305. [CrossRef]

20. Nicolaou, K.C.; Snyder, S.A. Chasing Molecules That Were Never There: Misassigned Natural Products and the Role of Chemical Synthesis in Modern Structure Elucidation. Angew. Chem. Int. Ed. 2005, 44, 1012-1044. [CrossRef]

21. Carroll, A.W.; Willis, A.C.; Hoshino, M.; Kato, A.; Pyne, S.G. Corrected Structure of Natural Hyacinthacine C1 via Total Synthesis. J. Nat. Prod. 2019, 82, 358-367. [CrossRef]

22. McOmie, J.F.W.; Watts, M.L.; West, D.E. Demethylation of aryl methyl ethers by boron tribromide. Tetrahedron 1968, $24,2289-2292$. [CrossRef]

23. Weissman, S.A.; Zewge, D. Recent advances in ether dealkylation. Tetrahedron 2005, 61, 7833-7863. [CrossRef]

24. Dodge, J.A.; Stocksdale, M.G.; Fahey, K.J.; Jones, C.D. Regioselectivity in the Alkaline Thiolate Deprotection of Aryl Methyl Ethers. J. Org. Chem. 1995, 60, 739-741. [CrossRef]

25. Vshivkov, A.A.; Gertman, G.A. Preparation of 2,4,6-substituted benzophenones. Zhurnal Vsesoyuznogo Khimicheskogo Obs. D. I. Mendeleeva 1984, 29, 105-106.

26. Kapdi, A.R.; Fairlamb, I.J.S. Synthesis of Macrocyclic Ketones Exploiting Palladium-Catalyzed Activation of Carboxylic Acids as an Enabling Step. New J. Chem. 2013, 37, 961-964. [CrossRef] 